\title{
Vertebrate Evolution and Extinction on Western and Central Mediterranean Islands
}

\author{
Josep Antoni Alcover Institut Mediterrani d'Estudis Avançats Cta de Valldemossa km 7, 5, \\ 07071 Ciutat de Mallorca, Balears, Spain
}

\begin{abstract}
The Mediterranean region, like other biogeographic regions located between continental plates, is rich in islands. Most of them are oceanic-like islands, i.e., islands that have been previously connected to the surrounding continents and are faunistically similar, but not identical, to oceanic island (because the island - continent connections occurred in a distant past, were of a short duration, and/or promoted a highly selective and limited faunal transfer). Insular (i.e., non-continental) vertebrate faunas are known in several Mediterranean islands from the Lower Miocene to Recent times. This paper presents an overview of these faunas in the Western and Central Mediterranean. I will emphasize the following points: 1 . Island's geological succession in the western Mediterranean area. 2. Faunistic successions occurring on the different islands. 3. Global analysis of the Mediterranean insular faunas. 4. Record and analysis of some extreme cases of insular evolution. 5. Extinction of the Mediterranean insular faunas.

The Mediterranean region has changed substantially from Eocene to current times. A record of the transformation of Mediterranean islands during geological time is presented in this paper. Some territories that were islands in the past (e.g., Gargano, Scontrone, Baccinello, Las Murchas) have been integrated into the mainland and are now continental areas displaying insular fossil faunas. They are considered "fossil islands". Merging of islands have also occurred (e.g., Mallorca, Sardinia, Crete) as well as some island splitting (e.g., Gymnesic islands).

In Sardinia, Mallorca, Menorca and Eivissa, there is a long fossil record documenting several faunistic successions. There, the faunistic turnover affected different taxonomic groups in different ways. Mammals were specially prone to extinction after new invasions.

The fossil insular vertebrate faunas from Mediterranean islands are peculiar. They differ both from typical oceanic insular faunas (usually devoid of mammals and amphibians) and the typical continental faunas (lacking endemic species). They are characterized by three main traits: (1) absence of mammal predators, (2) presence of terrestrial mammals and in some cases amphibians, and (3) high rates of endemic species, including some very bizarre taxa. Even though there are some exceptions, it is possible to define several global faunistic patterns for Mediterranean insular faunas.

Evolutionary changes in insular Mediterranean vertebrates have usually been small (i.e., alterations in body size and proportions that do not change substantially the life style of the species). Nevertheless, in some cases insular evolution produced very big changes (changes not only in body size and proportions, but also in assemblages of structures, implying substantial changes in the life style of the species). Some of the most noticeable insular evolutionary changes produced a variety of unusual taxa. Among amphibians, the subterranean Hydromantes from Sardinia, with four species still living on the island, displaying a ballistic chameleon-like retractile tongue, might be considered as examples. Among birds, the enormous owl Tyto gigantea, and the gigantic buteonine falcon Garganoaetus, as well as the terrestrial and probably flightless Cygnus falconeri. Among mammals, the bizarre Myotragus balearicus from the Pleistocene of the Gymnesic Islands (Mallorca and Menorca), a new genus of leporid, still undescribed, from the Pliocene of Menorca, the anthropomorph ape Oreopithecus bambolii from the Miocene of Baccinello (and Sardinia), Hoplitomeryx matthei and Deinogaleryx koenigswaldi from the Miocene of Gargano, and the dwarf hippo Phanourios minor from the Pleistocene in Cyprus, as well as some Pleistocene dwarf elephants and deer scattered over the Eastern and Central Mediterranean islands.
\end{abstract}


Finally, the extinction of the insular vertebrate faunas is analyzed. Extinctions are usually related to faunistic turnover, but there are some exceptions. The last extinction wave corresponds to human colonization of the islands. Current faunas of the Mediterranean islands include mainly humanintroduced mammalian species, but they usually retain the herpetological endemic assemblage of Pleistocene faunas.

Key words: Mediterranean islands / insular evolution / extinction / paleogeography

One of the greatest advantages of the study of the evolution on islands concerns the repeatability of the island "experiments". In ecology, extensive experimentation on islands has been performed to study the different parameters affecting insular ecosystems. In evolution, experiments have been naturally performed through geological time, and their results are mainly known from paleontological study in the islands.

Usually, two types of islands are known, oceanic and continental. A third kind of island can be recognized (Darlington, 1957, Alcover et al., 1998). We consider as oceanic islands those that have never been connected by dry land to any continent. The faunas of these islands show a high rate of endemicity, they are unbalanced (disharmonic) in comparison to continental faunas (i.e., display peculiar ratios of the animal ecological types, unrecorded on the continents), and they display species poverty at higher taxonomic levels (Carlquist, 1974; Blondel, 1979; Williamson, 1981). In contrast, continental islands are those that have been broadly connected to continents and their faunas are subsamples of the continental faunas, mainly harmonic, with low levels of endemicity and a low degree of species poverty. It is useful to consider a third kind of island, the oceanic-like islands (Alcover $e t$ $a l ., 1998)$. Oceanic-like islands are those that have been previously connected to continents but are faunistically similar to oceanic islands (because the island-continent connection occurred in the distant past, was of short duration, or did not promote faunal transfer).

On continental plates it is usual to find special groups of oceanic-like islands, the fringing archipelagoes (Darlington, 1957). The sea areas which separate the continental plates are frequently rich in such islands (e.g. the Antillean zone, located between the North American and South American plates, or the Wallacean region between the Asian and Australian plates; both are included in the socalled fringing archipelagoes by Darlington, 1957). This holds true for the Ryukyu islands and the Mediterranean islands.

The Mediterranean sea is an ocean in miniature (Margalef, 1985). It is a land-locked sea located between two of the largest continental plates, the Eurasian and African plates. Its geological and paleogeographic history is very complex (e.g., Maldonado, 1985). There are islands in the Mediterranean sea, although not with the size and abundance of other sea areas located between continental plates. In this aspect the Mediterranean sea is also an ocean in miniature.

The Mediterranean islands are best envisaged as an inter-continental mega-archipelago (Alcover et al., 1998), each segment having a different geological and biotic history. For example, during the Neogene there were some islands supporting terrestrial faunas in the western and central parts of the Mediterranean, but none in the eastern Mediterranean (Kotsakis, 1990, van der Made, 1996). It is thus not surprising that the oldest Mediterranean insular endemic species occur in the western zone, where 
the most ancient islands are located. Moreover, the western zone is, from a geological perspective, the most complex area in the Mediterranean, and is not yet sufficiently known.

The paleogeographical history of the different Mediterranean islands is complex. As in other regions, in the Mediterranean sea there are "continental" islands and "oceanic-like" islands. There are also islands which throughout geological time have undergone changes in their faunas and floras from an oceanic-like character to a continental character, and vice-versa. Moreover, there are "fossil islands", i.e., current continental areas which were in the past islands possessing now extinct faunas of oceanic-like character (e.g., Gargano, Scontrone, Baccinello, Las Murchas). Furthermore, there are known cases of merging of islands, having significant consequences for their faunas.

The Mediterranean islands are usually grouped according to their geographic location in the eastern, central or western Mediterranean. Their paleogeographical history is partly related to their location. Thus, insular faunas are known from the Neogene in both the western and central basins, but not in the eastern Mediterranean, where no island faunas younger than Pleistocene in age are known (e.g., Kotsakis, 1990, van der Made, 1996). Consequently, the most ancient species endemic to the Mediterranean islands have been found in the western zone, where the most ancient islands are placed.

This paper presents an overview of these faunas in the Western and Central Mediterranean. I will emphasize the following points: 1. Island's geological succession in the western and central Mediterranean area. 2. Faunistic successions on the different islands. 3. Global analysis of the Mediterranean insular faunas. 4. Record and analysis of extreme cases of insular evolution. 5. Extinction of the Mediterranean insular faunas.

\section{ISLAND'S GEOLOGICAL SUCCESSION IN THE WESTERN AND CENTRAL MEDITERRANEAN}

Recent summaries on the geological history of the Mediterranean appear in Maldonado (1985), Geel \& Roep (1998), and Rögl (1998). The Mediterranean region has changed substantially from Eocene to current times. It is convenient to introduce here a record of the Mediterranean islands through geological time. The establishment of insular vs. continental conditions in the different territories at each geological period is never deduced from tectonic and paleogeographical data. It comes from the biological characteristics of the fossil fauna (Dermitzakis \& Sondaar, 1977).

The birth of the Mediterranean Sea has been established as occurring at the Eocene-Oligocene boundary (e.g., Rögl, 1998). It was the result of the tectonic activity between the Eurasian and African plates. During Eocene, the Mediterranean area was occupied by an open ocean connected to the Polar Sea. This situation changed to a closed sea in the early Oligocene due to the tectonic relative movements of the Eurasian and African plates. The Western Mediterranean is a complex collision zone. The origin of the Western Mediterranean basin lies in a sequence of horizontal shearings induced by the subduction of the African plate under southern Europe. In the Oligocene, several fragments of the Iberian Peninsula, acting as small microplates, were cut off and started their movement to the east and south-east. Successive detachments of land masses occurred during the Miocene. At least one of the detached microplates collided with other mainland masses throughout the Miocene and Pliocene. 
There is no trace of insular faunas in the Mediterranean during the Paleogene. Some of the current islands (e.g., Mallorca, Sardinia) harbour fossil deposits from the Eocene and Oligocene, but the yielded faunas do not display clear signs of insularity. The first clearly true insular faunas from the Mediterranean are from Lower Miocene.

According to the paleontologic information we have, the following insular areas existed in the Western Mediterranean area in the past [see figure 1]:

\section{Lower Miocene}

Only one lower Miocene insular fauna is known from the Mediterranean area. It is the Oschiri fauna, in Sardinia (de Bruijn \& Rümcke, 1974). It is a highly disharmonic fauna, with only an undescribed ruminant (Sondaar, 1977), six rodents and three insectivores. The single species known from mainland deposits is a soricid, Crocidosorex antiquus. The remaining fauna is endemic. The fauna consists of a mixture of European and African elements. One of these African elements, Sardomys dawsonae is the largest sized known species of its family (Ctenodactylidae).

Ctenodactylids have never been described from the mainland European deposits. An Oligocene non-endemic fauna (thus, of continental type) including ctenodactylids is known from Mallorca (e.g., Adrover \& Hugueney, 1975).

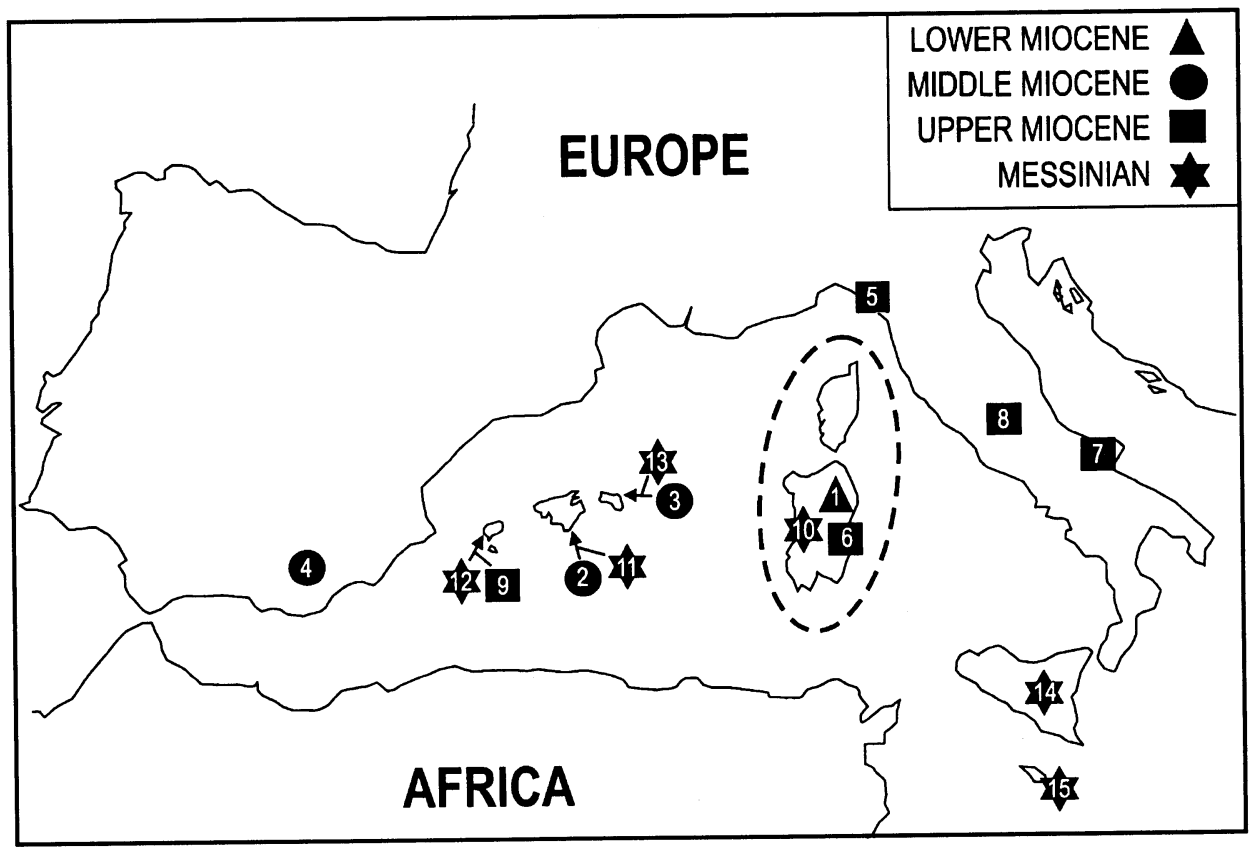

Fig. 1. Faunas that colonized the western and central Mediterranean islands before Pleistocene. 1. Oschiri fauna, Sardinia. 2. Gymnesicolagus fauna, Mallorca. 3. cf. Gymnesicolagus fauna, Menorca. 4. Las Murchas fauna. 5. Oreopithecus fauna, Tuscany. 6. Oreopithecus fauna, Sardinia. 7. Hoplitomeryx fauna, Gargano. 8. Hoplitomeryx fauna, Abruzzo. 9. Tyrrhenotragus fauna, Eivissa. 10. Nesogoral fauna, Sardinia (and Corsica?). 11. Myotragus fauna (Mallorca; in Menorca from Upper Pliocene). 12. Cova de Ca Na Reia fauna, Eivissa. 13. Giant leporid fauna, Menorca. 14. Leithia fauna, Sicily. 15. Malta fauna. 


\section{Middle Miocene}

Three Middle Miocene insular faunas are known. In Mallorca two deposits (the coal layers of Santa Margalida and Sant Llorenç) delivered remains of the same middle Miocene fauna (Mein \& Adrover, 1982, Adrover et al., 1983-1984). This fauna, consisting of an ochotonid (Gymnesicolagus gelaberti) and three glirids (Carbomys sacaresi, Margaritamys llulli and Peridyromys ordinasi), has been dated as Langhian-Serravalian. The ochotonid is the largest known species in the family. A similar fauna is known from Menorca (karstic deposit of Punta Nati 2), where an ochotonid closely related to Gymnesicolagus, a glirid, and a giant tortoise have been recorded (Quintana, 1998). The third insular fauna from the middle Miocene comes from the deposit of Las Murchas (Granada, Spain). This deposit contains insular-evolved descendants of Pseudodryomys and Peridyromys (Martin-Suárez et al., 1992).

These insular faunas suggest that in the Middle Miocene there was an arc of islands near the coast of the Spanish mainland. Probably all the islands in this arc (Mallorca, Menorca, Las Murchas) were colonized by the same fauna, which displays only local differences.

\section{Upper Miocene}

At least four and probably five insular faunas are known from this period. The fossil fauna from Maremma (Tuscany, Italy) embraces four stratigraphic levels (V0 to V3). The first three levels (V0V2) clearly reflect an insular situation, while the fourth (V3) contains a mainland fauna. This insular fauna has been accurately dated paleontologically and radiometrically between 9.5 and $6.5 \mathrm{Myr}$ (Engesser, 1989).

The fauna of the different deposits from Maremma is poor, disharmonic and endemic. It contains a primate (Oreopithecus bambolii), two bovid lineages (Tyrrhenotragus and Maremmia), an ochotonid (Paludotona etruria), a suid (Eumaiochoerus), two lutrine lineages (Paludolutra and Tyrrhenolutra), a soricid, and four rodents (Huerzelerimys, Parapodemus, Kowalskia and Anthracoglis). The origin of this fauna seems to be European (Moyà-Solà et al., in press), although some authors consider some taxa (Oreopithecus and Tyrrhenotragus) to be of African origin.

A second fauna containing Oreopithecus and Maremmia lorenzi, an undetermined bovid, and a crocodile, dated in 8.4 +/- 0.4 Myr has been recently described from Sardinia (Cordy \& Ginesu, 1994). This fauna suggests also a general colonization event during the Upper Miocene from Southern Europe to the Mediterranean islands. These are faunas of a tropical character, like the Pleistocene West Indian faunas.

A third insular fauna of the Mediterranean, probably Upper Miocene (Freudenthal, 1971, 1976; Moyà-Solà et al., in press) or Lower Pliocene (de Giuli \& Torre, 1984), has been recovered in Gargano (Foggia, Italy). Like Maremma and Las Murchas, Gargano was a fossil archipelago. The Gargano fauna is highly disharmonic, poor in species and highly endemic. It includes the five-horned artiodactyl Hoplitomeryx (Hoplitomerycidae), the giant insectivore Deinogaleryx, a lutrine, several rodents, as well as a giant owl (Tyto gigantea) and several eagle-sized buteonine falcons (Garganoaetus).

Another fauna attributed to the Upper Miocene or Lower Pliocene has been recently described from Scontrone (Abruzzo, Central Italy). This fauna contains also Hoplitomeryx, as the most representative element (Rustioni et al., 1992; Mazza \& Rustioni, 1996). Other components of this 
fauna are Crocodylus, an undetermined chelonian, and an undetermined lutrine. An isolated finding of Prolagus in Capo di Fiume Quarry (Palena, Abruzzo, Central Italy; Mazza et al., 1995) could be also related to this fauna as well as to the Gargano fauna.

Finally, another fauna containing endemic mammals, probably Upper Miocene or perhaps intraMessinian, is known from Ses Fontanelles (Eivissa). This fauna is still poorly known. The assignment to Upper Miocene is only tentative, based on the presence in the fauna of Tyrrhenotragus sp., a species apparently related to Tyrrhenotragus gracillisimus from the level V2 from Maremma (Agustí \& Moyà-Solà, 1990). This fauna contains two bovids, two rodents, an insectivore, and a leporid, as well as a lizard and a large tortoise.

\section{THE MESSINIAN TRANSGRESSION AND THE POST MESSINIAN CONFIGURATION OF THE MEDITERRANEAN AREA}

During the Messinian, the last Miocene episode, as a result of the closure of the connection with the Atlantic ocean produced by the collision between the African and Eurasian plates, the Mediterranean sea dried up. All the western and central Mediterranean islands were affected by the so-called Messinian crisis (Hsü, 1972, Hsü et al., 1973, 1977; Maldonado, 1985). In the western Mediterranean basin, large deposits of evaporites of this epoch, proving the drying up, have been found (Hsü et al., 1973, 1977). Between 5.7 and 5.35 million years ago (Gautier et al., 1994) the drying up of the Mediterranean sea produced the accumulation of large amounts of evaporites at the bottom of the western Mediterranean basin and gave rise to the connection of the western Mediterranean islands to the surrounding continental mainlands. The areas which were previously insular remained connected to the surrounding continents, although this connection was basically in the form of salty deserts. These salty deserts apparently acted as biogeographic barriers producing a strong filtration of immigrants (Alcover, 1987). There is evidence that a global phenomenon of faunistic turnover affected all the western Mediterranean islands during the Messinian crisis (e.g., Agustí \& Moyà-Solà, 1990). At this epoch, a globally similar fauna, with regional differences, colonized different islands of the region (see Figure 1). The opening of the strait of Gibraltar isolated the faunas, which thereafter started to evolve independently on each island or archipelago.

\section{Lower Pliocene}

There are common Lower Pliocene taxa in the three current western Mediterranean archipelagoes. The mammalian faunas that arrived to the western Mediterranean islands during the Messinian are usually characterized by the presence of glirids and caprines, as well as shrews and lagomorphs in some cases. The opening of the strait of Gibraltar (5.35 million years ago) gave rise to a geographic configuration of the western Mediterranean sea similar (although not identical) to the current one. Subsequent to the opening of the strait of Gibraltar, both the paleogeographical and faunistic histories of the three archipelagoes developed in different ways. It seems that no further connections between these islands and the surrounding continents have been established. Only a few species of the assemblage which immigrated to the western Mediterranean islands during the Messinian survived until the human colonization wave in the Holocene.

The island of Menorca may have been an exception to the Messinian colonization by glirids and 
caprines of the Western Mediterranean islands. It is probable that the pre-Messinian Gymnesicolagus fauna was substituted by a peculiar insular vertebrate assemblage, with a giant tortoise (Cheirogaster gymnesica), a giant leporid (aff. Alilepus n. sp.), and a large sized dormouse, Muscardinus cyclopeus. This fauna has not been well dated yet, and its assignment to the Pliocene is only tentative. An alternative hypothesis assigns this fauna an intra-Messinian age (Agustí \& Moyà-Solà, 1990).

The first known insular fauna from Sicily, Monte Pellegrino (Thaler, 1972), has been usually attributed to the Pliocene or Lower Pleistocene. This fauna contains a ctenodactylid (Pellegrinia panormensis), a large-sized wood mouse (Apodemus), a glirid (Leithia), and a leporid (Hypolagus). The colonization of Sicily may have occurred during the Messinian (Kotsakis, 1990) or the Pliocene (Thaler, 1972).

\section{FAUNISTIC SUCCESSIONS ON THE DIFFERENT ISLANDS}

Insular faunal successions from several Western Mediterranean islands are known. In Gargano, Sardinia, Mallorca, Menorca and Eivissa, the faunal turnover consisted in the substitution of an insular fauna by another insular fauna. In other islands (e.g., Maremma, last turnover in Gargano, Sicily), the faunal turnover involved replacement of an insular fauna by a mainland fauna.

In Sardinia, the faunal succession starts with the Lower Miocene Oschiri fauna (first insular fauna), followed by the Upper Miocene Oreopithecus fauna (second insular fauna), the Messinian Nesogoral fauna (third insular fauna) and later by the Biharian fauna of Megaloceros (Figure 2). Sardinia, together with Corsica, is considered a microplate detached from the Iberian Peninsula and displaced to the east to reach its current position. The current presence in Corsica and Sardinia of several amphibians with poor dispersal potential and with close relatives in the Pyrenees, reveals the existence of permanently emergent land on both islands during microplate movement. The question whether these lands constituted an unity or were split into several unconnected islands, remains unresolved. Some authors hold that Sardinia was constituted by several isolated islands in the past. Probably they assembled during the Messinian to become a single large island, remaining undivided during all the Pliocene and Quaternary.

The nature of the first assumed faunal turnover in Sardinia is not clear. We don't know whether it affected all the pre-Sardinian islands or only a part of them. It is not clear when this occurred. The second faunal turnover happened during the Messinian. At this time, the Nesogoral fauna colonized the island and started to evolve under insularity conditions. This faunal turnover had a great effect on the mammalian faunas. The next faunal turnover occurred apparently during the Biharian (800.000 year ago), and perhaps affected all the Cirno-Sardinian island, functioning as a unit. At this time, an overseas immigration and a faunistic change occurred. This faunistic change was less extensive than the previous one. Recent findings in Corsica (e.g., Salotti et al., 1997, Bonifay et al., 1998) suggest that the paleogeographical history of the Cirno-Sardinian islands may be more complex than previously considered.

The faunal succession in Mallorca is also unclear. The Middle Miocene faunas of Gymnesicolagus probably survived until the Messinian crisis. A sharp faunistic change occurred during the Messinian. The entire mammalian fauna (the Gymnesicolagus fauna) was substituted by a new fauna (the Myotragus fauna), which had arrived by crossing the surrounding saline deserts and started to evolve 


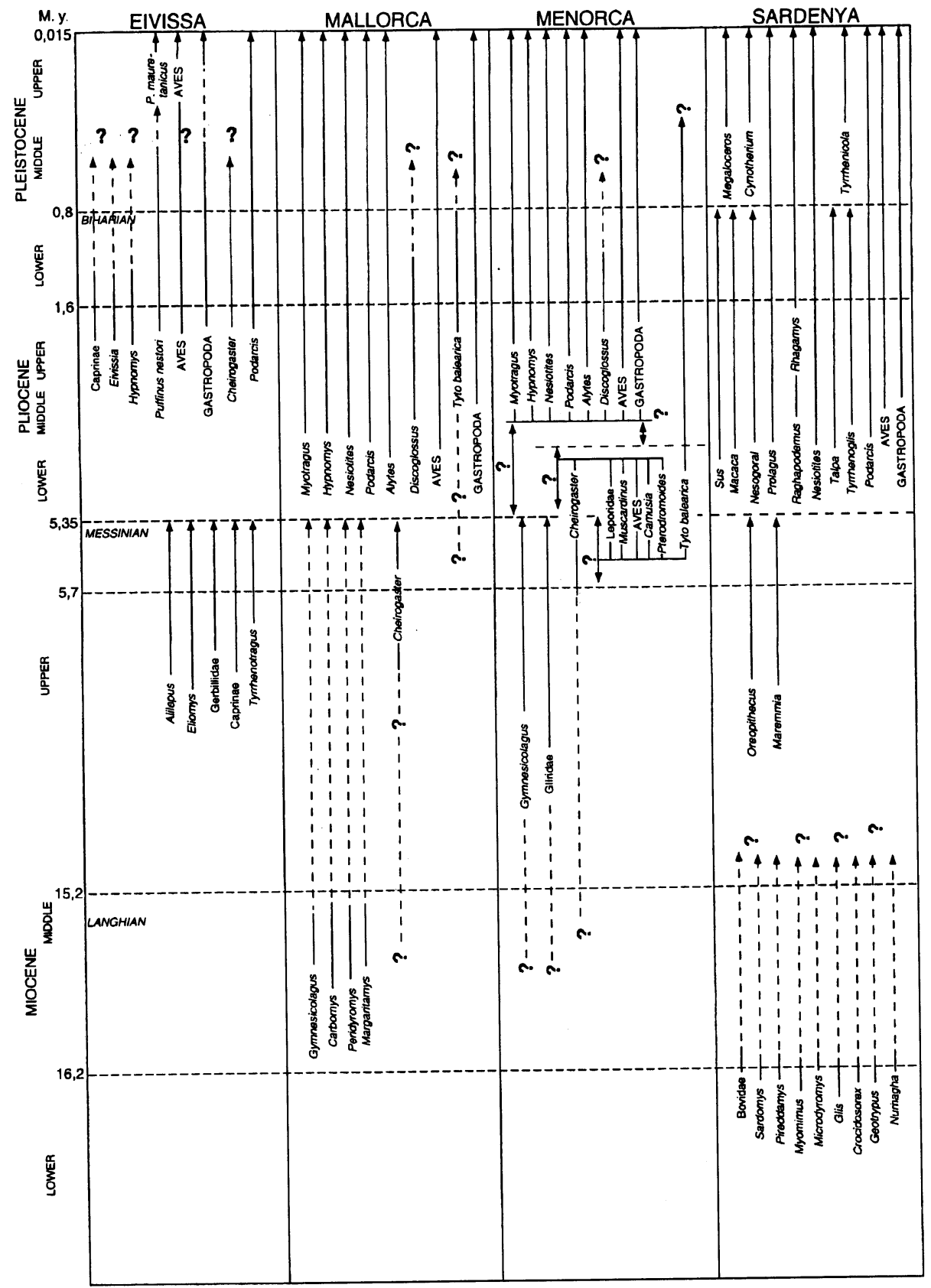

Fig. 2. Faunal succession in the western Mediterranean islands.

under insularity conditions. This fauna of Messinian origin survived until the arrival of humans.

In Menorca, the faunal succession is slightly different. The first insular fauna, probably coming from Middle Miocene or Upper Miocene, includes a Gymnesicolagus-like pika. This fauna survived until the Messinian. At this time a sharp faunal turnover occurred. The Gymnesicolagus fauna was 
replaced by another one containing a highly modified leporid, still not described. There is still some debate about the age of the leporid fauna, but it seemingly flourished during the Lower and Middle Pliocene. Later, a new faunal turnover took place in Menorca, and this fauna was replaced by the Myotragus fauna. The age of this turnover is unclear, but it seems unquestionable that it occurred before the Pliocene-Pleistocene boundary. It has been suggested that it took place during the Upper Pliocene, about 2.3 Myr ago, when the first glaciations started, Mallorca and Menorca then being connected for the first time by a landbridge. During the Pleistocene, the faunal history of Mallorca and Menorca are the same, probably with only small regional differences, because these islands became re-connected during each glaciation.

The faunal turnover in Eivissa is also unclear. The presumably upper Miocene fauna of Ses Fontanelles probably disappeared during the Messinian. The fauna from Cova de Ca Na Reia, containing two glirids and a bovid, probably colonized the island during the Messinian. Later, some time between the Pliocene and the Middle Pleistocene, the mammalian fauna from Eivissa disappeared without mammalian turnover (Alcover et al., 1994).

In Sicily and Malta, the faunal successions are also unclear. The fauna of Monte Pellegrino partially disappeared. It is the case of Pellegrinia panormensis, Apodemus maximus and Hypolagus sp. (Thaler, 1972). Nevertheless, one of the Monte Pellegrino genus (Maltamys) may have survived. The second faunistic episode recorded in Sicily is represented by the characteristically insular fauna of Spinagallo. This fauna contains the dwarf Mammuthus falconeri as well as a hippo, Hippopotamus pentlandi, and two glirids of the genus Leithia. This fauna has been attributed to the middle Pleistocene.

In Malta, the Pliocene-Pleistocene insular fauna, derived from Sicilian stocks, includes a giant tortoise, Cheirogaster robusta, a terrestrial swan, Cygnus falconeri, a dwarf hippo, Hippopotamus melitensis and two or three glirids.

\section{GLOBAL ANALYSIS OF THE MEDITERRANEAN INSULAR FAUNAS}

This chapter tries only to introduce the main common traits of the Mediterranean insular faunas, as well as some of their peculiar aspects. The complexity of the area's paleogeography and the changing climate during the Neogene makes impossible the establishment of a single model for the Mediterranean islands. In contrast, this high diversity, both paleogeographic and climatic, helps us to view the Mediterranean insular faunas from a wider perspective.

The first feature to be pointed out is that each island has had its own history. This is a general rule in the study of evolution on islands. Only in the case of the actual merging of islands can highly shared biogeographic histories be identified. This has been the case for Mallorcan and Menorcan faunas from the Upper Pliocene to Recent times, and probably Corsican and Sardinian faunas from the Biharian to Recent times. In these cases, close islands separated by narrow channels of shallow waters acted as faunistic units, even for species with very reduced dispersal abilities.

With only one exception, all Mediterranean islands that have been paleontologically explored, whit surface areas greater than $100 \mathrm{sq}$. km, have yielded land mammals. The exception is Eivissa (Alcover et al., 1994). The upper Pleistocene fauna from Eivissa consists only of huge quantities of 
birds, as well as one lizard species and some bat species. No terrestrial mammals have been found despite the fact that fossil bone recovery now exceeds 150000 elements. The vertebrate communities were structured there in a very peculiar way, unparalleled on the other Mediterranean islands, but with strong similarities with the Pleistocene Hawaiian fauna (Seguí \& Alcover, in press).

In comparison with the faunas of the surrounding continents, the Mediterranean insular faunas display a depletion of mammalian carnivores. In fact, this depletion is not as important as on truly oceanic islands or on other oceanic-like islands. The Pleistocene fauna of Corsica and Sardinia includes a small canid, Cynotherium sardous (e.g., Eisenmann, 1990). Only two other insular canids are known in the world, Dusicyon australis from the Falkland Islands and Urocyon littoralis from the Californian Channel Islands, both poorly differentiated from their mainland relatives. On the other hand, as a characteristic of the insular Mediterranean faunas, several otters from different islands are known: Lutrogale cretensis from the Upper Pleistocene in Crete, Sardolutra ichnusae, Megalenhydris barbaricina from the Sardinian Pleistocene, Algarolutra majori from the Pleistocene in Corsica and Sardinia, Lutra euxena from the Pleistocene in Malta, Lutra trinacriae from the Pleistocene in Sicily, Paralutra garganensis from the Miocene in Gargano, and Paludolutra campenii, Paludolutra maremmana and Tyrrhenolutra helbingi from the Miocene in Maremma. Apparently, not all the islands harboured otters, but their presence in the Mediterranean islands was general. Some species (e.g., Lutrogale cretensis) acquired a more terrestrial way of life, but others were aquatic and lived on the coast of the islands, preying basically upon marine animals (Willemsen, 1992). It seems that other mustelids lived in other Mediterranean islands (e.g., Enhydrictis galictoides in Sardinia and "Mustelercta" arzilla in Sicily), but they are currently insufficiently known.

Probably as a consequence of the scarcity of mammals as predators in the Mediterranean islands, the birds of prey assumed an important role. Birds of prey are prone to evolve on islands and eventually give rise to endemic species. On islands, birds are commonly the main predators of middleand large-sized vertebrates (Alcover \& McMinn, 1994).

Species belonging to Aquila have been found in different islands in the Mediterranean: Aquila chrysaetos in the Pleistocene of Mallorca, Aquila sp. cf. Aquila heliaca of Corsica, and the large Aquila chrysaetos szimurgh in the Pleistocene of Crete. These eagles preyed on the large endemic mammals. In Eivissa, the only Mediterranean island without mammals, lived a large Haliaeetus albicilla. The presence of sea eagles as top predators is usual on islands without mammals and with a noticeable abundance of middle-sized birds (Anseriformes, Procellariiformes). On the fossil tropical islands of Gargano lived giant eagle-sized buteonine hawks, Garganoaetus freudenthali and $G$. murivorus. Both were huge predators and there are few doubts that they acted as predators of mammals, preying on the rodents, insectivores and artiodactyls from these islands. Buteonine hawks are known to have evolved to very big size only in the fossil islands of Gargano and in the Pleistocene Antilles. There are two possible explanations for the presence of giant buteonine hawks instead of true eagles on Gargano and the West Indies (Alcover \& McMinn, 1994). First, neither archipelago may have been colonized by eagles. In the Palearctic, the spread of true eagles may have taken place after the Pliocene. The fossil record also indicates that true eagles colonized the nearctic region only recently. On the other hand, both archipelagos offered to avian predators an overlapping range of prey sizes, thus allowing buteonine hawks (and barn owls) to evolve and acquire giant body size.

Some owl species evolved also in the Mediterranean islands. The largest species, Tyto gigantea, 
lived on the tropical islands of Gargano. It was a large barn owl, displaying a size similar to Tyto riveroi from the Pleistocene of Cuba. Other insular Mediterranean species were the small Bubo insularis from Corsica and Sardinia, and the long legged Athene cretensis from Crete, Athene angelis from Corsica and Athene n. sp. from Sicily.

The study of the insular Mediterranean fossil faunas allows for the recording of different patterns of colonization and extinction. The faunistic turnover related to terrestrial connections affected always the majority of the fauna, while faunistic turnovers related to overseas immigration affected only some groups. Examples of wide turnover linked to the establishment of terrestrial connections are the Messinian turnover or the Pliocene Menorcan turnover. A case of turnover related to overseas immigration is that of the Sardinian Biharian. Thus, the Messinian transgression represents a "grande coupure" for the Mediterranean insular faunas. During this transgression a complete mammalian turnover took place on the Western Mediterranean islands, causing the loss of all species that lived there prior to this event while a new stock of mammalian species immigrated. The mammalian Messinian immigration is characterized by the arrival of caprines and dormice to the islands. Whether the faunal turnover affected other taxonomic groups to the same extent as the mammals is a debatable question. There is some evidence showing that amphibians and gastropods were not greatly affected by the Messinian salinity crisis (e.g., Paul \& Altaba, 1992).

Climatically, two types of islands can be identified in the Mediterranean. During the Miocene and Lower and Middle Pliocene, the Mediterranean region had a tropical-subtropical climate and consequently the insular faunas evolved in clearly tropical-subtropical environments. During the Upper Pliocene an important change in climate (Keigwin \& Thunell, 1979, Thunell, 1979, Emiliani, 1992) and vegetation (Julià \& Suc, 1980, Bertoldi et al., 1989, Combourieu-Nebout, 1993) occurred throughout the Mediterranean basin. This change involved the deviation, from a warm and humid climate of tropical-subtropical character, with only very small annual oscillations, to a colder, drier one, with a more Mediterranean-type character, with important climatic oscillations, and leading to the beginning of the succession of glacial and interglacial stages. Vegetational changes paralleled to climate changes between 3.3 and $2.36 \mathrm{My}$, when a vegetation of tropical character was replaced by a one of Mediterranean character, which would also be more abrasive (Julià \& Suc, 1980, Bertoldi et al., 1989, Suc et al., 1992, 1995, Combourieu-Nebout, 1993). About 2.36 My ago the first northern glaciation occurred in Cenozoic time (Shackleton \& Opdyke, 1977).

The evolution of insular species is related both to climate and vegetation. Islands under tropicalsubtropical climatic regimes have always been richer in species and supported more complex ecological webs than do islands under a Mediterranean climate. In Mediterranean islands, the evolution of species on islands that changed from a tropical-subtropical climate to a Mediterranean climate is particularly interesting. The evolution of at least two genera (Myotragus, Oreopithecus) has been strongly affected by such changes.

\section{RECORDS AND ANALYSES OF EXTREME CASES OF INSULAR EVOLUTION}

The evolution of species on islands has produced a considerable amount of evidence of evolutionary processes (e.g., Darwin 1859, Carlquist 1974). Insular species are the evolutionary consequences of 
adaption to peculiar insular environments. The endemic islanders frequently differ from their mainland relatives in size and shape. There is a large record of species originating in islands that hardly differ from their mainland relatives. Nevertheless, in some cases, the differences are enormous. In fact, in some cases insular evolution has produced very bizarre animals and plants (Carlquist, 1974). These animals represent extreme cases of insular evolution, and they are frequently considered as "curiosities" or "anecdotal cases". Nevertheless, they are the most highly adaptive body-plans to the peculiar insular environments. They are very important to an understanding of how evolution acts and how animals evolve. They allow for the identification and measurement of the constraints affecting evolution on the mainland. They also help us understand how large changes in life style can be acquired throughout small changes in development patterns. Thus, it is not adequate to consider them merely as curiosities or evolutionary anecdotes.

Like on other archipelagoes, in the Mediterranean islands the evolutionary changes undergone by vertebrates have usually been small (i.e., some changes in body size and proportions that did not change substantially the style of life of the species). Nevertheless, in some cases insular evolution of vertebrates on the Mediterranean islands produced oddities displaying changes not only in body size and proportions, but also in assemblages of structures, with concomitant changes in the function of muscles, implying therefore substantial changes in the life style.

Amphibians are widespread in the pre-human Mediterranean insular faunas. Some amphibians (e.g., Rana cretica, Hyla sarda) colonized the islands by overseas immigration. Others (e.g., Alytes muletensis) immigrated to the islands by crossing the Messinian saline deserts of the Mediterranean. Finally, others (e.g., Euproctus) are in the islands due to a vicariance process. The only amphibians that deserve to be included in the select club of extreme evolutionary cases seem to be the four stillliving species of Hydromantes (Nascetti et al., 1996). Nevertheless, it is not clear if their extraordinary modifications are directly related to insularity. The salamanders of genus Hydromantes are the most extreme feeding specialists of their family (Pletodonthidae). The members of this genus possess tongues that can be shot with great accuracy to preys located several centimeters away (Deban $e t$ al., 1997).

Only a few of the reptiles that evolved in the Mediterranean islands can be considered to represent extreme cases of insular evolution. Generally, insular Mediterranean species are endemic forms slightly differentiated from mainland species. Nevertheless, several species of large tortoises lived in the past on some of the Mediterranean islands. Namely, Cheirogaster gymnesica from the Upper Miocene or Lower Pliocene in Menorca, Cheirogaster sp. A from the Miocene in Mallorca and Cheirogaster sp. B from the Pliocene to middle Pleistocene in Eivissa and Cheirogaster robusta probably from the Pliocene in Malta. These tortoises are incompletely known, and there are no noticeable differences from mainland relatives other than their big size .

Some bizarre birds lived on the Mediterranean islands. A big terrestrial swan lived in Malta, Cygnus falconeri, probably flightless. This is the only known case of a terrestrial swan. In the Western Mediterranean islands some endemic extinct bird species are known from the faunas of Maremma, Gargano, Sardinia, Mallorca, Menorca and Eivissa (Ballmann, 1973, Alcover et al., 1992). Only a few of them can be considered as cases of extreme evolutionary development: the giant owl Tyto gigantea (Ballmann 1973, Mlíkovsky, 1998) and the buteonine eagle-sized hawks of the genus Garganoaetus from Gargano. The first one, Tyto gigantea, was a barn owl of very big size, similar to Bubo bubo. 
Garganoaetus represents an eagle-sized buteonine hawk.

In the Mediterranean islands, other extreme cases of insular evolution are known, mainly among mammals. Some of the Mediterranean insular representatives of this Class have no parallels anywhere.

One of the most intriguing insular species of the Mediterranean is Oreopithecus bambolii. At first considered to be related to the Middle Miocene African hominoids (Harrison, 1985, 1986) it has been recently identified as an insular derivative of European Dryopithecus (Pongidae; Moyà-Solà \& Köhler, 1997). Its skull and dentary morphology have been interpreted as having followed a paedomorphic pattern within the apes. Currently, it is the only known ape to have evolved under insularity conditions. Oreopithecus bambolii shows clear adaptions to upright walking (Köhler \& Moyà-Solà, 1997). Among these are the peculiar morphology of the lordotic lumbar region, the configuration of the knee joint, the great ischial spine, short pubic symphysis and mainly the peculiar foot morphology and proportions. The acquisition of the upright locomotion from an arboreal ancestry is correlated with the absence of mammalian predators. The vegetation of the Maremman islands was probably very different from the vegetation of mainland Dryopithecus habitats. This point can be established from the dental evolution of Maremmia, in some ways convergent on the teeth of Myotragus. Both probably originated as an adaption to browse on a more abrasive vegetation. The adaption to these peculiar insular environments implied the change of life style in Oreopithecus. The evolution of the hand of Oreopithecus is probably related to the acquisition of upright walking with an improved grasping capability that includes hominid-like precision grip capability (Moyà-Solà et al., 1999). Some of its morphological changes were acquired through a paedomorphic process. Apparently, other insular primate species on other islands abandoned also arboreality to adopt a more terrestrial way of life (e.g., Paralouatta varonai from Cuba, MacPhee, 1996, Archaeolemur and Hadropithecus from Madagascar, Fleagle 1988), but in these cases the acquired locomotion was semiterrestrial baboon-like or Presbytis-like (MacPhee, pers. com). Probably, the acquisition of bipedal locomotion has been possible in Oreopithecus, like in humans, because its ancestor Dryopithecus, like modern apes, possessed an upright trunk posture (orthogradism) combined with dorsoventral thoracic flattening. This was not the case in Paralouatta from Cuba, Hadropithecus from Madagascar or Macaca from Sardinia and Sulawesi. The ancestors of these taxa exhibited horizontal trunk posturs with lateral thoracic flattening. Consequently, the significance and understanding of Oreopithecus evolution is very important to understanding hominid evolution.

Another extreme case of insular evolution is Deinogaleryx. This genus includes five described species, one of them, Deinogaleryx koenigswaldi, being the largest known erinaceomorph. This is an enormous insectivore, unparalleled anywhere. It is known from the Gargano faunas (Butler, 1981). It was an erinaceomorph galericine with a body length of $60 \mathrm{~cm}$, with a relatively large head and short trunk, and with an estimated weight of $5-13 \mathrm{~kg}$. It displayed a huge head and was a slow-moving animal (Freudenthal, 1972). There is no clear evidence concerning its relationships. Its evolutionary significance is absolutely speculative (Butler, 1981, Mazza \& Rustioni, 1996).

A very bizarre artiodactyl, Hoplitomeryx, comes from the same Gargano deposits (Leinders, 1984). This genus has been also recently identified from the Turolian deposit of Scontrone (Abruzzo, Central Italy, Mazza \& Rustioni, 1996). It is one of the most amazing ruminants ever found. It was a short-legged artiodactyl, with a still undescribed postcranial skeleton. The only postcranial feature 
recorded so far is that the cannon bone is always fused with the naviculo-cuboid, a trait characteristic of some endemic insular ruminants (Leinders \& Sondaar, 1974). Its skull has been carefully described by Leinders (1983). Hoplitomeryx had five horncores (two above each orbit and one nasal) and large dagger-like upper canines (in males). Other relevant cranial characteristics are the strongly developed nuchal part of the skull, the posteriorly directed foramen magnum and the very large, inflated bullae (Leinders, 1984). Its mainland ancestor is unknown. Leinders (1984) suggested Amphimoschus as a candidate. Nevertheless, Micromeryx, a small antlerless cervoid from the Vallesian and Turolian of Europe seems to be a more adequate candidate (Moyà-Solà $e t$ al., in press).

On the Balearic island of Menorca, a giant and highly modified leporid (as yet undescribed) lived probably during the Lower and Middle Pliocene. It was a dog-sized hare with modifications of the legs indicating a low gear locomotion. This kind of locomotion is unknown in mainland hares.

Perhaps the most known "extreme case" of insular evolution in the Mediterranean islands is Myotragus balearicus Bate 1909, from Mallorca and Menorca. The fossil record of its evolutionary lineage is very complete. It is presumed that its ancestors colonized Mallorca from the mainland during the Messinian, and Menorca from Mallorca during the Upper Pliocene. As a result of its insular evolution, the terminal species of the lineage, Myotragus balearicus, displays a large number of highly derived characters (autapomorphies), that can be interpreted as adaptions to the insular environment.

Myotragus balearicus was a bizarre artiodactyl. In the adult stage, it had only one evergrowing incisor in each dentary, like rodents. Recently (Bover \& Alcover, in press) this incisor has been identified as the $\mathrm{dI}_{2}$, thus like the mandibular evergrowing incisor of rodents and lagomorphs. The check teeth are reduced in number. The skull displays a shortened face, and consequently the eyes are frontally located (Alcover et al., 1981, Marcus, in press). The nasal cavity is very small (MacPhee, pers.obs.) and the size of the eyes is relatively large. The combination of both characteristics suggests that perception of the world by Myotragus was very unusual, more visual than odorous, thus in sharp contrast with other artiodactyls. Usually, artiodactyls have very good olfactory abilities and their perception of the world through smell is very important. In the studied Myotragus balearicus brain casts (Desachaux, 1961; Angelelli et al., 1985), the size of the olfactory bulbs is small in Myotragus balearicus, while the size of the foramen lacerum anterior, may have been relatively larger than in other bovids. The shape of its body, with shortened legs, was also very bizarre. Its locomotion has been described elsewhere as an extreme case of "low gear locomotion" (Sondaar, 1977). This locomotion has been assumed as highly adaptive to rocky environments. An alternative hypothesis is that the locomotion of Myotragus was related to the support of a very heavy body. Actually, Myotragus balearicus was a very heavy animal, with body weight estimates around $50-70 \mathrm{~kg}$ for specimens with a shoulder height of $45-50 \mathrm{~cm}$.

\section{EXTINCTION OF THE MEDITERRANEAN INSULAR FAUNAS}

Many extinctions and local disappearances are recorded in the biogeographical history of Western Mediterranean islands. An overview of the extinctions occurred from the Messinian onwards has been recently published (Alcover et al., in press). Several patterns of extinction can be identified from the study of the Mediterranean islands. 
Some extinctions affecting single species have been recorded, but searching for their immediate causes is usually a difficult task. In the Mediterranean region there is also a good record of mass extinctions. This type of extinction is more prone to be analyzed.

With the arrival of humans into the islands, a global extinction of the fauna happened. This episode is relatively recent and we know its extent relatively well. For land mammals, all the endemic species of the Western Mediterranean islands disappeared. Taking all the Mediterranean islands together (Western, Central and Eastern), the human-related mammalian extinction affected $90 \%$ of species (Alcover et al., 1998). Nevertheless, the extent of this extinction episode had a very reduced effect on other taxa. Only a frog species disappeared (Alytes talaioticus from Menorca), while none of the reptile species did.

This extinction episode strongly affected birds (Alcover et al., 1992, Seguí \& Alcover, in press). Extinctions of birds have been non-random, but deterministic. All the endemic raptors disappeared, as well as the large-sized Falconiforms, Anseriforms and Gruiforms. The avian communities changed dramatically. The current ones are apparently less diverse and numerically less important than the prehuman bird communities.

The extinction episode linked to human settlement of the islands affected, consequently, different vertebrates groups in very different ways. This episode is related to the immigration of humantransported species. In some groups, like terrestrial mammals, there is a big turnover, with strong changes in species composition and with a very important increase in species numbers on different islands. In other groups, like reptiles and amphibians, there is no turnover, but an increase in species numbers on each island. The composition of the current faunas of these groups is a mixture of the old prehuman inhabitants together with the newly arrived species. Finally, for other groups, like birds and bats, the faunal change is not very clear; apparently there was no turnover, but a decrease in the species numbers on each island.

Throughout geological time, mass extinction episodes non related to the presence of humans have been numerous in the Mediterranean islands. Unfortunately, at present our data on their extent are mainly based on the mammalian faunas. The fossil record of other vertebrates for Neogene insular faunas is scarce.

Two main types of mammalian mass extinction can be identified. Those with faunal turnover vs. extinctions without faunal turnover. Obviously, a definitive land connection between an island and nearby mainland (Gargano, Maremma) implies the extinction of the insular fauna. In the Mediterranean, the only mass extinction of mammals (and other vertebrates and no vertebrates) known to have occurred without turnover but with a continuity of the insular situation, was reported for Eivissa. The faunas from the Pliocene included three mammals, a giant tortoise, as well as a lizard species, bats, birds and more than 20 gastropod species. This fauna suffered a mass extinction process at some still-indeterminated time (probably during the middle Pleistocene). All the mammalian species become extinct (without replacement), as did the tortoise and about $70 \%$ of the gastropod species. The causes for this catastrophic event remain unknown (Alcover et al., 1994).

Other mass extinction episodes recorded for the Mediterranean islands seem to have produced either a partial or a total faunal turnover. Two types can be also identified. On one hand, there are examples of faunal turnover related to terrestrial connections (e.g., the faunal turnover of the Messinian, or the replacement of the Pliocene Menorcan fauna by the Mallorcan fauna after the 
establishment of the first connection of both islands). In these cases, the original terrestrial mammal fauna was entirely replaced by a new one. On the other hand, there are also cases of faunal turnover not related to terrestrial connections. One instance seems to have been the Biharian replacement of the Sardinian fauna. During the Biharian, Sardinia was joined to Corsica and Corsica was separated from the mainland only by a very narrow channel $6-10 \mathrm{~km}$ wide. At this time some overseas immigrants colonized the island and a faunal turnover took place. This turnover affected only part of the original fauna. In fact, the large species of the original fauna became extinct, while new immigrants colonized the island. Small mammals were scarcely affected.

The lessons from extinction patterns are that extinction affects different taxonomic groups to differing extent. Some taxa (e.g., terrestrial mammals) are more prone to extinction than others (e.g., reptiles and amphibians), and the same event can have very different consequences in different taxonomic groups.

Similar to extinction, the immigration of species follows some patterns. One very interesting pattern consists of the Messinian colonization of different Mediterranean islands by a similar fauna, containing caprines and dormice, and eventually lagomorphs. Evidently, there are regional differences (related to the geographical situation and size of the islands) among the islands, but all of them can be considered colonized by a similar fauna. During the Langhian, also some dormice and some ochotonids colonized different islands.

ACKNOWLEDGMENTS The author wishes to acknowledge the collaboration of Dr. Damià Jaume and Dr Ross MacPhee. Dr. Hiroyuki Otsuka invited me to participate in "The Ryukyu Islands" International establishing an interinsular bridge between Mediterranean and Japanese islands. He patiently never complained about my Mediterranean schedules. I want to acknowledge him for his invitation and hospitality.

\section{REFERENCES}

Adrover, R., Agustí, J., Moyà, S. \& Pons, J., 1983-1984. Nueva localidad de micromamíeros insulares del Mioceno medio en las proximidades de Sant Llorenç en la isla de Mallorca. Paleontologia $i$ Evolució 18: 121-129.

— \& Hugueney, M., 1975. Des rongeurs (Mammalia) africains dans une faune de l'Oligocène élévé de Majorque (Baléares, Espagne). Nouv. Arch. Mus. Hist. Nat. Lyon 13, suppl.: 11-13.

Agustí, J. \& Moyà-Solà, S., 1990. Neogene-Quaternary Mammalian faunas of the Balearics. In: Azzaroli, A., ed., International Symposium on "Biogeographical Aspects of Insularity (Rome, 1822 May 1987)", Atti Convegni Lincei, Accad. Nac. Lincei 85: 459-468.

Alcover, J. A., 1987. Mamífers i illes. Síntesi de models de colonització en biogeografia histórica i la seva aplicació a la Mediterrània. Paleontologia i Evolució 21: 69-74.

— Florit, F., Mourer-Chauviré, C. \& Weesie, P. D. M., 1992. The avifaunas of the isolated Mediterranean Islands during the middle and upper Pleistocene. In: Campbell, K. E., ed., Papers in Avian Ornithology. Honoring Pierce Brodkorb. Science Series, Natural History Museum of Los Angeles County 36: 273-283.

— M Minn, M., 1994. Predators of vertebrates on Islands. BioScience 44: 12-18. 
- — \& Altaba, C. R., 1994. Eivissa: A Pleistocene ocean like Island in the Mediterranean sea. National Geographic Research and Exploration 10: 236-246.

__ Moyà-Solà, S. \& Pons-Moyà, J., 1981. Les Quimeres del Passat. Els Vertebrats Fòssils del Plio-Quaternari de les Balears i Pitiüses. Monografies Científiques, Edit. Moll 1: 1-260.

- Sans, A. \& Palmer, M., 1998. The extent of extinctions of mammals on islands. $J$. Biogeography 25: 913-918.

- Seguí, B. \& Bover, P. (in press). Extinctions and local disappearances of vertebrates in the western Mediterranean Islands. In: MacPhee, R. D. E., ed., Explaining Quaternary Extinctions: Humans and Other Catastrophes. Plenum Press, NYC.

Altaba, C. R., 1998. Testing vicariance: melanopsid snails and Neogene tectonics in the Western Mediterranean. J. Biogeography 25: 541-551.

Angelelli, F., Gliozzi, E. \& Malatesta, A., 1985. L'encefalo di Nesogoral melonii (Dehaut), nemoredino quaternario della Sardegna. Boll. Serv. Geol. Italia 103: 35-52.

Ballmann, P., 1973. Fossile Vögel aus dem Neogen der Halbinsel Gargano (Italien). Scripta Geologica 17: 1-75.

Bertoldi, R., Río, D. \& Thunell, R., 1989. Pliocene-Pleistocene vegetational and climatic evolution of the south-central Mediterranean. Palaeogeography, Palaeoclimatology, Palaeoecology 72: $263-$ 275.

Blondel, J., 1979. Biogéographie et Ecologie, 171 pp. Masson, Paris.

Bonifay, E., Bassiakos, Y., Bonifay, M. F., Louchart, A., Mourer-Chauviré, C., Pereira, E., Quinif, Y. \& Salotti, M., 1998. La Grotte de la Coscia (Rogliano, Macinaggio): étude préliminaire d'un nouveau site du Pléistocène superieur de Corse. Paleo 10: 17-41.

Bover, P. \& Alcover, J. A. (in press). The evolution and ontogeny of the dentition of Myotragus balearicus Bate 1909 (Artiodactyla, Caprinae): Evidences from new fossil data. Biol. J. Linn. Soc., London.

Bruijn, H. de \& Rümcke, C. G., 1974. On a peculiar mammalian association from the Miocene of Oschiri (Sardinia). I \& II. Proc. Kon. Ned. Akad. Wetensch., ser. B 77: 46-79.

Butler, P. M., 1981. The giant erinaceid insectivore Deinogaleryx freudenthal from the upper Miocene of Gargano, Italy. Scripta Geologica 57: 1-72.

Carlquist, S., 1974. Island biology. Columbia University Press, New York, Nat. Hist. Press.

Combourieu-Nebout, N., 1993. Vegetation response to upper Pliocene glacial / interglacial cyclicity in the central Mediterranean. Quaternary Research 40: 228-236.

Cordy, J. M. \& Ginesu, S., 1994. Fiume Santo (Sassari, Sardaigne, Italie): un nouveau gisement à Oréopithèque (Oreopithecidae, Primates, Mammalia). C. R. Acad. Sc. Paris, Sér. II, 318: 697-704.

Darlington, P. J., 1957. Zoogeography: the geographical distribution of animals, 675 pp. John Wiley \& Sons, Inc., New York.

Deban, S. M., Wake, D. B. \& Roth, G., 1997. Salamander with a ballistic tongue. Nature 389: 27-28.

Dermitzakis, M. D. \& Sondaar, P. Y., 1979. The importance of fossil mammals in reconstructing paleogeography with special reference to the Pleistocene Aegean archipelago. Ann. Géol. Pays Helléniques 29: 808-840.

Desacheaux, C., 1961. Moulages endocraniennes de bovidés fossiles. Ann. Paleontologie 47: 51-73.

Eisenmann, V., 1990. Juvenile characters and systematic affinities of the skulls of Cynotherium 
sardous, an endemic Pleistocene canid from Sardinia. C. R. Acad. Sc. Paris 310: 433-439

Emiliani, C., 1992. Planet Earth. Cosmology, Geology, and the Evolution of Life and Environment, 715 pp. Cambridge University Press.

Engesser, B., 1989 The late Tertiary small mammals of the Maremma region (Tuscany, Italy). 2nd part: Muridae and Cricetidae (Rodentia, Mammalia). Boll. Soc. Paleont. It. 28: 227-252.

Fleagle, J., 1988. Primate adaptation and Evolution, 486 pp. Academic Press, Inc., New York.

Freudenthal, M., 1971. Neogene vertebrates from the Gargano Peninsula, Italy. Scripta Geologica 3: 1-10.

- 1972. Deinogaleryx koenigswaldi nov. gen., nov. Spec., a giant insectivore from the Neogene of Italy. Scripta Geologica 14: 1-19.

_ 1976. Rodent stratigraphy of some Miocene fissures fillings in Gargano (prov. Foggia, Italy). Scripta Geologica 37: 1-23.

Gautier, F., Caluzón, G., Suc, J. P. \& Violanti, D., 1994. Age et durée de la crise de Salinité Messinienne. C. R. Acad. Sci. Paris 318 (II): 1103-1109.

Geel, T. \& Roep, T. B., 1998. Oligocene to middle Miocene basin development in the Eastern Betic Cordilleras, SE Spain (Vélez Rubio Corridor - Espuña): reflections of west Mediterranean platetectonic reorganizations. Basin Research 10: 325-343.

Giuli, C. de \& Torre, D., 1984. Species interrelationships and evolution in the Pliocene endemic faunas of Apricena (Gargano Peninsula, Italy). Geobios, Mem. spec. 8: 379-383.

Harrison, T., 1985.African oreopithecids and the origin of the family. Amer. J. Phys. Anthropol., Abstracts 62 (2): 180.

, 1986. A reassessment of the phylogenetic relationships of Oreopithecus bambolii Gervais. J. Hum. Evol. 15: 541-583.

Hsü, K. J., 1972. Origine of saline giants: a critical review after the discovery of the Mediterranean evaporites. Earth-Sci. Rev 8: 371-396.

, Cita, M.B. \& Ryan, W. B. F., 1973. Late Miocene dessication of the Mediterranean. Nature 242: $240-244$.

—, Montadert, L., Bernouilli, D., Cita, M. B., Erikson, A., Garrison, R. E., Kidd, R. B., Mèlierés, F., Müller, C. \& Wright, R., 1977. History of the Mediterranean Salinity Crisis. Nature 267: 399403.

Julià, R \& Suc, J. P., 1980. Analyse pollinique des dépôts lacustres du Pléistocèe inférieur de Banyoles (Bañolas, Site de la Bòbila Ordis - Espagne): un élément nouveau dans la reconstitution de l'histoire paléoclimatique des régions méditerranéennes d'Europe Occidentale. Géobios 13: 519.

Keigwin Jr., L. D. \& Thunell, R. C., 1979. Middle Pliocene climatic change in the western Mediterranean from faunal and oxygen isotopic trends. Nature 282: 294-296.

Köhler, M. \& Moyà-Solà, S., 1997. Ape-like or hominid-like? The positional behavior of Oreopithecus bambolii reconsidered. Proc. Nat. Acad. Sci. USA 94: 11747-11750.

Kotsakis, T., 1985. Vertebrati insulari e paleogeografia: alcuni esempli. Boll. Soc. Paleont. Ital. 24: 225-244.

, 1990. Insular and non Insular Vertebrate Fossil Faunas in the Eastern Mediterranean Islands. In: Azzaroli, A., ed., International Symposium on "Biogeographical Aspects of Insularity" (Rome, 
18-22 May 1987). Atti Convegni Lincei, Accad. Nac. Lincei 85: 289-334.

Leinders, J., 1984. Hoplitomerycidae fam. nov. (Ruminantia, Mammalia) from Neogene fissure fillings in Gargano (Italy). Part 1. The cranial osteology of Hoplitomeryx gen. nov. and a discussion on the classification of Pecoran families. Scripta Geologica 70: 1-68.

— Sondaar, P. Y., 1974. On functional fussions in footbones of Ungulates. Z. f. Säugetierkunde 39: 109-115.

MacPhee, R. D. E., 1996. The Greater Antillean monkeys. Rev. Ciènc. 18: 13-32.

Made, J. van der 1996. Pre-Pleistocene land Mammals from Crete. Monographs in World Archaeology 28: 69-79.

Maldonado, A., 1985. Evolution of the Mediterranean basins and a detailed reconstruction of the Cenozoic paleoceanography. In: Margalef, R., ed., Western Mediterranean, pp. 17-59. Pergamon Press, Oxford.

Marcus, L. F., 1998. Variation in selected skeletal elements of the fossil remains of Myotragus balearicus, a Pleistocene bovid from Mallorca. Acta Acad. Scient. Hungar 44: 113-137.

Margalef, R., ed., 1985. Western Mediterranean. Pergamon Press, Oxford.

Martin-Suárez, M., Freudenthal, M. \& Agustí, J., 1993. Micromammals from the middle Miocene of the Granada basin (Spain). Geobios, Mém. spec. 6: 451-463.

Mazza, P. \& Rustioni, M., 1996. The Turolian fossil artiodactyls from Scontrone (Abruzzo, Central Italy) and their paleoecological and paleogeographical implications. Boll. Soc. Paleont. Ital. 35: 93-106.

$\longrightarrow$ - Aruta, G. \& Di Carlo, E., 1995. A Messinian Prolagus from Capo di Fiume Quarry (Palena, Abruzzo, Central Italy). Boll. Soc. Paleont. Ital. 34: 55-66.

Mein, P. \& Adrover, R., 1982. Une faunule de mammifères insulaires dans le Miocène moyen de Majorque (Îles Baléares). Geobios, Mem. spec. 6: 451-463.

Mlíkovsky, J., 1998. A new barn owl (Aves: Strigidae) from the early Miocene of Germany, with comments on the fossil history of the Tytoninae. J. f. Ornithologie 139: 247-261.

Moyà-Solà, S. \& Köhler, M., 1997. The phylogenetic relationships of Oreopithecus bambolii. Comptes Rendues de l'Académie des Sciences, Paris 324: 141-148.

- \& Rook, L., 1999. Evidence of hominid-like precision grip capability in the hand of the Miocene ape Oreopithecus. Proc. Natl. Acad. Sci. USA 96: 313-317.

- Quintana, J., Alcover, J. A. \& Köhler, M. (in press). Endemic Island Faunas of the Mediterranean Miocene.

Nascetti, G., Cimmaruta, R., Lanza, B. \& Bullini, L., 1996. Molecular Taxonomy of European Plethodontid Salamanders (Genus Hydromantes). J. Herpetology 30: 161-183.

Paul, C. R. C. \& Altaba, C. R., 1992. Els mol.luscs terrestres fóssils de les Illes Pitiües. Boll. Soc. Hist. Nat. Balears 35: 141-169.

Quintana, J., 1998. Aproximación a los yacimientos de vertebrados del Mio-Pleistoceno de la isla de Menorca. Boll. Soc. Hist. Nat. Balears 41: 101-117.

Rögl, F., 1998. Palaeogeographic considerations for Mediterranean and Paratethys Seaways (Oligocene to Miocene). Ann. Naturhist. Mus. Wien 99: 279-310.

Rustioni, M., Mazza, P., Azzaroli, A., Boscagli, G., Cozzini, F., Di Vitto, E., Masseti, M. \& Pisano, A., 1992. Miocene vertebrate remains from Scontrone, National Park of Abruzzi, Central Italy. 
Rend. Fis. Acc. Lincei, Ser. 9, 3: 227-237.

Salotti, M., Bailon, S., Bonifay, M. F., Courtois, J. Y., Dubois, J. N., Ferrandini, J., Ferrandini, M., La Milza, J. C., Mourer-Chauviré, C., Popelard, J. B., Quinif, Y., Real-Testud, A. M., Miniconi, C., Pereira, E. \& Persiani, C., 1997. Castiglione 3, un nouveau remplissage fossilifère d'âge pléistocène moyen dans le karst de la région d'Oletta (Haute-Corse, France). C. R. Acad. Sci. Paris 324, ser. IIa: 67-74.

Seguí, B. \& Alcover, J. A. (in press). Comparison of paleoecological patterns in insular bird faunas: a case study from the Western Mediterranean and Hawaii. Smithsonian Contributions to Paleobiology.

Shackleton, N. J. \& Opdyke, N. D., 1977. Oxygen isotope and paleomagnetic evidence of early Northern Hemisphere glaciation. Nature 270: 216-219.

Sondaar, P. Y., 1977. Insularity and its effects on mammalian evolution. In: Hecht, M. K., Goody, P. C. \& Hecht, B. M., eds., Major Patterns in Vertebrate Evolution. pp. 671-707.

Suc J. P., Bertini A., Combourieu-Nebout N., Diniz F., Leroy S., Russo-Ermolli E,. Zheng Z., Bessais E. \& Ferrier J., 1995. Structure of West Mediterranean vegetation and climate since 5.3 Ma. Acta Zoologica Cracoviensa 38: 3-16.

$\longrightarrow$, Glauzon, G., Bessedik, M,. Leroy, S., Zheng, Z., Drivaliari, A., Roiron, P., Ambert, P., Martinell, J., Domenech, R., Matias, I., Julià, R. \& Anglada, R., 1992. Néogène et Pléistocène inférieur du sud de la France et du nord-est de l'Espagne. Cahiers de Micropaléontologie 7: 165186.

Thaler, L., 1972. Les rongeurs (Rodentia et Lagomorpha du Monte Pellegrino et la question des anciens isthmes de la Sicile. C. R. Acad. Sci. Paris 274: 188-190.

Thunell, C. R., 1979. Pliocene-Pleistocene paleotemperatures and paleosalinity history of the Mediterranean Sea: results from DSDP Sites 125 and 132. Marine Micropaleontology 4: 173-187.

Willemsen, G. F., 1992. A revision of the Pliocene and Quaternary Lutrinae from Europe. Scripta Geologica 101: 1-115.

Williamson, M., 1981. Island Populations, 286 pp. Oxford University Press, Oxford. 


\section{J. A. ALCOVER＼cjkstart地中海西部の島嶼群における脊椎動物の進化と絶滅}

大陸の間に位置する他の生物地理的領域と同様に，地中海には島が多い。その多くは，太洋島状である， 例えば，それらの島々では動物相の移動が極端に選択的に限られて行われてきた。島嶼（非大陸性）の脊 椎動物相は, 前期中新世（約2000万年前）から現在までのいくつかの地中海の島々で知られている。この 論文では, 地中海西部におけるそれらの動物相の概観を行う。

次の点を強調したい。

1. 地中海西部地域の島々における地質系統

2. それぞれ異なった島々における動物相の変遷

3. 地中海島嶼動物相のグローバルな解析

4. 島嶼型進化のの極端な例の記録と解析

地質時代の記録からみると, 地中海地域における始新世から今日までの古地理は, 実質的に変化してき た。かって島々であった幾つかの地域（例えば Gargano, Baccinello, Murches）は本土とくっついていた ことがあるが, 現在では島嶼型化石相を産する大陸の一部である。それらは “化石島 (fossil island)” と 考えられる。また, この時期には, いくつかの島の分裂（例えば Gymnetic island）と同様に, いくつか の島と島の連結（例えばMallorca, Sardinia, Creteの島々）が記録されている。

Sardinia, Mallorca, Menorca, Eivissaの島々では, いくつかの動物相の連続的な遷移を証明する長期に わたる化石記録が存在する。動物相の入れ替わり (faunal turnover) は, それぞれ異なった方法で, 異なつ た分類群に及んでいる。先住の哺乳類は新しい侵入 (事件) 後, 絶减する傾向にあった。

地中海地域の島々の島嶼型化石脊椎動物は特殊である。それらは典型的な太洋島の動物群（通常哺乳類， 両生類を欠如している）と，典型的な大陸の動物群（固有種を欠如している）とは異なっている。それら は3つの特殊性によって特徵づけられている。

1）哺乳類を食べる食肉類がいない

2) 両生類がいる

3）大変に変わつた分類群を含む高次分類群の固有種がいる

例外があるにせよ, 地中海の島嶼型動物相のパターンを定義することは可能である。地中海の島嶼型動 物相を説明する進化的な変化は小さかった（例えば, 体のサイズとそのプロポーションにおけるいくつか の変化一それらは種の実質的な生活様式を変えることは無い)。それでも，いくつかの例として，地中海の 島々における脊椎動物の島嶼型進化は, 大変大きな変化を起こした（体のサイズやプロポーションのみな らず, 生活様式の実質的変化を意味する体構造においても変化する)。それらは，この論文において紹介す る。地中海の島々における最も著しい進化的変化の例のいくつかは, 次のような例の分類群に起こった。 両生類では，例えば Sardinia 島の亜陸棲の Hydromantes 属 4 種が依然として島に生息しており，それら は, カメレオンのような伸縮自在の舌を使っている。鳥類では, 大変大きなフクロウ Tyto gigantea, 巨大 なワシタカ科 Garganoaetus, 同様に, 陸棲のおそらくは飛べない鳥 Cygnus falconeri, 哺乳類では Balearic 諸島 (Mallorca, Menorca) の更新世から産する奇妙なウシ科の Myotragus balearicus, Menorcaの鮮新 統から産する未記載のウサギの新属, Baccinello島とSardinia島の中新統から産する人類に似たヒトニザ ル Oreopithecus bambolii, Garganoの鮮新統から産する Hoplitomeryx matthei やDeinogaleryx koenigswaldi, Cyprosの更新世から産するコビトカバのPhanourios minor, さらに東部および中部地中海に散在する更新 世の矮小型ゾウとシカなどである。

このように, 島嶼型動物相の絶滅は解析された。絶滅は通常, 動物相の入れ替わりに関係している。し かし，例外もある。最後の危機の波は，島への人類の移住（colonization）である。地中海の島々の現在 の動物相は, 基本的には人類が持ち込んだ哺乳類の種を含むが，しかし，通常それらは第四紀動物相に属 する爬虫類の固有種を伴っている。 